Article

\title{
The Politicisation of the European Central Bank and the Bundestag
}

\author{
Anna-Lena Högenauer \\ Institute of Political Science, University of Luxembourg, 4366 Esch-sur-Alzette, Luxembourg; \\ E-mail: anna-lena.hoegenauer@uni.lu
}

Submitted: 6 May 2019 | Accepted: 25 June 2019 | Published: 27 September 2019

\begin{abstract}
The European Central Bank (ECB) became one of the key actors during the Eurozone crisis. However, its prominent role was not without controversy. On one hand, the Eurozone was stabilised, no member state defaulted, and no state had to leave the Euro. On the other hand, the ECB had to stretch its mandate, expand its policy remit, and adopt so-called 'unconventional' monetary policies. These attempts to depoliticise political challenges through a technocratic approach reduced the opportunities for democratic contestation, but they also bred frustration that led to politicisation. This article studies to what extent this politicisation affected the perception of the ECB in national parliaments. For this purpose, it studies the extent to which ECB policy has become politicised in the German Bundestag through an analysis of plenary debates from 2005 to 2018. The Bundestag represents an unlikely case for politicisation despite wide-spread criticism of the ECB in the media, as Germany was traditionally attached to creating a highly independent ECB, until recently had no major Eurosceptic right-wing parties, and parliamentary scrutiny of the national central bank is low. However, by studying the salience of ECB policies, the polarisation of opinion in the parliament, as well as the range of actors participating in the debates, this article finds that the ECB's policies have become politicised and the subject of scrutiny and dissatisfaction.
\end{abstract}

\section{Keywords}

banking union; Bundestag; European Central Bank; Eurozone crisis; Germany; national parliaments; plenary debates; politicisation

\section{Issue}

This article is part of the issue "Parliamentary Impact on "Politicised" Policies", edited by Christine Neuhold (Maastricht University, The Netherlands) and Guri Rosén (University of Oslo, Norway).

(C) 2019 by the author; licensee Cogitatio (Lisbon, Portugal). This article is licensed under a Creative Commons Attribution 4.0 International License (CC BY).

\section{Introduction}

As the EU has been shaken by multiple crises in the last 15 years, more and more aspects of it have become politicised. The European Central Bank (ECB) was one institution whose policies proved controversial despite the technocratic nature of central banking. The ECB filled a vacuum when national governments failed to agree on a way to tackle high levels of sovereign debt. In the process, it became the 'key actor in the EU's economic governance' (Fromage \& Ibrido, 2018, p. 295). The task of keeping the Euro stable required it to expand its policies. As a result, 'its competences stretched to their limits' (Fromage \& Ibrido, p. 296). However, in this empowerment, Scicluna and Auer (2019) see a wider problem, namely the tendency to resolve political challenges through a technocratic approach. However, by reducing the opportunities for regular democratic contestation, the EU may be fuelling frustration and thus politicisation and contestation. In addition, with the creation of the European banking union, the ECB gained new powers in recent years and now supervises the largest banks under the Single Supervisory Mechanism. These powers have now become more salient, as weak banking supervision is seen as one of the factors contributing to the financial crisis of 2008.

The problem with technocratic governance is that it has the potential to pit non-majoritarian actors that are meant to be independent and apolitical (e.g., the ECB) against political actors (e.g., parliaments) that feel that issues that ought to be resolved politically are removed from their grasp by the former. Studies into the scrutiny of EU affairs in national parliaments since the crisis have shown that EU governance, in general, is becoming more 
salient and controversial among parliamentarians (Auel \& Raunio, 2014; Closa \& Maatsch, 2014; Wendler, 2014). In EU policy-making, there is thus a certain fight emerging for competencies between non-majoritarian and political actors, making it particularly interesting to investigate the extent to which parliaments have tried to extend their scrutiny of the ECB and whether this has led to politicisation.

The question of whether ECB policy has become politicised in the German parliament, the Bundestag, is particularly important in this context. The German case is important due to the political and economic weight of the country in the Eurozone. Also, the German parliament is not a likely case for politicisation. Of course, the ECB's Eurozone crisis policies did not resonate well with the German public and media, providing an incentive to scrutinise the ECB. There were, in particular, wide-spread fears about the negative impact of low interest rates on savers and the fear that TARGET2 (Trans-European Automated Real-time Gross Settlement Express Transfer System) imbalances, the bail-out programmes, the ECB's quantitative easing ${ }^{1}$ measures, and the banking union would create a 'transfer union'. In addition, the Bundestag has fairly strong scrutiny powers in EU affairs in general (Auel, Rozenberg, \& Tacea, 2014), and particularly with regard to specific Eurozone crisis policies. The German parliament, the Bundestag, has extensive oversight and veto powers over the European Financial Stability Fund, for example (Höing, 2013). Moschella also emphasizes that the Bundestag is the only Eurozone parliament that has both ex-ante and expost scrutiny powers over lending programmes that affect the German budget (Moschella, 2017). Finally, Auel and Höing (2014) show that the Bundestag is one of the more active debaters of crisis policies.

On the other hand, while the Bundestag has considerable scrutiny powers over EU affairs in general and crisis policies in particular, neither the European nor the German legal framework provide it with formal scrutiny powers over the ECB. It can, of course, debate ECB policy, but it has no formal means of influence nor can it summon ECB representatives. As an extremely independent central bank, the ECB is protected against undue political influence, which also means that formal parliamentary powers of oversight are extremely weak-even with regard to the European Parliament (EP). Furthermore, the German parliament has no tradition of actively scrutinising central banks. The Bundesbank was already independent before the Euro was created, and recent studies show that the Bundestag is barely scrutinizing the Bundesbank due to how strictly it respects its independence (Högenauer \& Howarth, 2018). Högenauer and Howarth (2018) show that the Bundesbank was only mentioned in 12 debates in a 3-year period, and then only in 1-2 speeches per debate. One would, therefore, also expect parliamentary scrutiny of the ECB to be low in Germany, as the ECB was created as a highly independent central bank on the insistence of Germany and based on the model of the Bundesbank. In addition, Wonka (2016) argues that Germany is an unlikely case for politicisation of EU affairs in general because the public and elites are broadly pro-European and anti-European right-wing parties were not yet represented in the Bundestag during the early crisis years. Thus, if the Bundestag were to increasingly debate ECB policy, it would be a very strong indication of the politicisation of a policy area that-in the German case-was traditionally barely scrutinized.

This article aims to analyse through the case of the German Bundestag whether ECB policy has become politicized in the course of the Eurozone crisis. Politicisation will be analysed through three dimensions, based on the framework developed by De Wilde, Leupold and Schmidtke (2016): the salience of the policy, the polarisation it triggers, and the range of actors involved in the debate.

\section{A Brief Overview over the ECB's Policies since the Financial Crisis}

When the financial crisis first erupted in 2007/2008, the ECB's response was initially muted. Unlike the US Federal Reserve, which lowered interest rates to stimulate the economy, the ECB initially maintained and even increased the interest rate to stave off inflation. It was only in late 2009 that the ECB also rapidly lowered the interest rate when faced with the threat of an economic recession, from 3.25 per cent in October 2008 to 0.25 per cent in April 2009 (ECB, n.d.). The monetary policy of the ECB then became increasingly expansionary as the Eurozone crisis took hold.

Over time, the ECB deployed both 'conventional' and 'unconventional' policies to stabilize the Eurozone. As part of its conventional policies, the ECB continued its low interest rate policy. In 2014, it decided to impose a negative interest rate on deposits at the ECB: This means that banks that 'parked' liquidity at the ECB no longer received interest, but had to pay interest to the ECB. The goal was to prevent the credit market from drying up by encouraging banks to invest in the economy instead. In addition, the ECB lowered the base interest rate to zero per cent in 2016. More controversially, it moved towards fixed-rate full allotment in 2008 , i.e., it agreed to provide unlimited credit to banks at a fixed interest rate (Flachmeyer \& Paul, 2018).

In addition, the ECB used so-called 'unconventional' policies that were not part of its standard approach to monetary policy. One of these was the provision of emergency liquidity assistance (ELA) that allowed central banks to provide solvent banks with liquidity in return for relatively low securities. This measure played a

\footnotetext{
1 'Quantitative easing' refers to the increase in the money supply (liquidity) by a central bank. In this case, for example, the ECB purchases sovereign bonds from the market and thereby releases money into the market in the hope that this injection of liquidity will encourage lending and investment and ultimately stimulate economic activity.
} 
role in the management of the Greek crisis, for example. A series of new bond-buying programmes allowed the ECB to purchase bonds, and particularly sovereign debt, on the secondary markets. What started with the 2010-2012 Security Markets Programme (SMP), led to the announcement of an outright monetary transactions (OMT) programme in 2012, when the ECB declared that it would do 'whatever it takes' to stabilize the Euro. The OMT never had to be put in practice, as the announcement itself reassured markets sufficiently to bring down the interest rates on sovereign debt (Högenauer \& Howarth, 2019). Finally, in 2015 the Expanded Assets purchase programme was introduced. The goal of these policies was to increase inflation when it was close to zero per cent and to stimulate the economy. At its height (2016 to early 2017), the ECB bought bonds worth 80 billion Euro per month on average. After March 2017, the volumes were progressively reduced (Flachmeyer \& Paul, 2018).

The ECB was also a member in the 'Troika', a decisionmaking group consisting of the ECB, the Commission, and the International Monetary Fund. The Troika played a role in the bail-outs of Cyprus, Greece, Ireland, and Portugal by requesting austerity measures and reforms in return for financial support. It was controversial that a nonmajoritarian, technocratic institution such as the ECB should impose conditions on elected governments that would have important repercussions on their citizens.

In 2012, EU policy-makers decided to create a banking union with the ECB as chief supervisor over large Eurozone banks. For the ECB, the advantage was that this removed information asymmetries and allowed it to extend liquidity to solvent banks only. Previously, it had to rely on the national supervisory bodies for information. However, the drawback was that being both a lender to banks and a supervisor of banks created a permanent risk of a conflict of interest, and raised questions about the ECB's ability to separate these functions in-house.

Many of these policies would have been unthinkable before the crisis, and the effect of the emergency credits, punitive interests, and bond-buying programmes was heightened controversy (Flachmeyer \& Paul, 2018). Similarly, it would have been inconceivable that the ECB would instruct member state governments to pursue specific economic and fiscal policies. Thus, overall, the ECB was, on the one hand, a key actor in the crisis, and at times the only one who could act in the face of stalemate in the EU's political institutions (Flachmeyer \& Paul, 2018). But on the other hand, its policies had increasingly noticeable redistributive effects (Goodhart \& Lastra, 2018), stretched the mandate defined in the Treaty and led to a rise in the level of public distrust of the ECB (Tesche, 2018).

\section{The ECB and Parliaments}

As the ECB's role in the crisis was very prominent, it is difficult to conceive these policies as purely techno- cratic decisions that can be legitimized in terms of output legitimacy. The fact that the effects of ECB policy on different groups of citizens became visible and often involved a trade-off between different interests means that output legitimacy would mean different things to different people (Goodhart \& Lastra, 2018). In addition, the problem with this type of technocratic policy-making is that it shifts power away from majoritarian and democratically legitimized institutions to technocratic and nonmajoritarian institutions that are not electorally accountable. Börzel and Risse (2018, p. 83) estimate that this approach breeds dissatisfaction, and that 'we have to consider that depolitisation through supranational delegation during the Euro crisis has ultimately led to more, not less politicisation.'

The political impact of the crisis policies can also be felt in the case of Germany. While 65 per cent of Germans trusted the ECB prior to the crisis in spring 2007, by 2009 this had already shrunk to 52 per cent (European Commission, 2007, 2009). Trust in the EU also plummeted during the crisis (Wonka, 2016). Leupold (2016) finds that the number of German press articles on EMU nearly doubled in 2010/2011 compared to 2007 and that the ECB's evolving policies triggered strong opposition in the German media. Heft (2017) also confirms that support for financial aid is much lower in the German press.

The political elite also increasingly voiced scepticism in the media. Quantitative easing was seen as an illegal attempt to finance the debt of member states, the interest rate was perceived as being artificially low with the potential to harm savings banks, insurers and savers and the growing TARGET2 balances between debtor and creditor countries were eyed critically. A German CB president resigned over disagreements with the ECB's policies, ministers such as Wolfgang Schäuble publicly blamed the ECB for the rise of right-wing populism in Germany, and the ECB's OMT programme was challenged before the German Constitutional Court (Högenauer \& Howarth, 2019).

In the midst of the crisis, Draghi, therefore, made an unprecedented visit to the Bundestag on the 25th of October 2012 to explain the OMT that was heavily criticized by German politicians and the president of the Bundesbank, Jens Weidmann. About 100 MPs attended the session, which was targeted at the budget and finance committees and the European affairs committee (Wiesmann \& Steen, 2012).

Despite this rare visit, national parliaments have virtually no influence over the ECB. This is not just due to the fact that most national parliaments had had weak competences in EU affairs until they started to claw back powers of scrutiny in the 1990s and 2000s (Raunio, 2009; Winzen, 2012). Rather, the fact is that ECB policymaking is a different beast from 'ordinary' EU policymaking. As both the ECB's mandate and its independence from political institutions are enshrined in the Treaty, neither the EP nor the national parliaments are able to 
give it mandates or restrict its actions through legislation. Nevertheless, there are now two mechanisms that bring the ECB in contact with parliaments. Firstly, there is the traditional dialogue with the EP, the Monetary Dialogue, based on art. 284-3 TFEU since 1998. More recently, since the creation of a European banking union with the ECB as the supervisory authority, the ECB has agreed to a 'Banking Dialogue' that includes both the EP and National Parliaments (Amtenbrink \& van Duin, 2009; Fromage \& Ibrido, 2018). However, these Dialogues are purely consultative.

That said, parliaments do have the power to scrutinize and debate ECB policy publicly, even if they cannot directly influence it. Whether they do so and how they do so is in a sense a measure of how accepted ECB policy is. In this context, it is important to note that parliamentary scrutiny does not necessarily reduce the central bank's independence: In fact, if it is used as a tool to encourage the central bank to explain and justify its actions, it can facilitate greater transparency and accountability fostering trust between political and technocratic institutions. However, unlike scrutiny in general, the politicisation of central banking is arguably problematic. The current set up of the Eurozone with high a highly independent central bank relies on the assumption that the ECB can be a technocratic and neutral actor that defends the best interest of the whole within a clear mandate, and that the political institutions will perceive it as such and allow it to exercise its powers freely. A high level of politicisationi.e., controversy or criticism - of ECB policy in other institutions can be interpreted as a sign that the trust these institutions have that the ECB is indeed a technocratic and neutral defender of the common interest with a clear mandate is eroding. After all, technocratic institutions rely largely on output legitimacy-but is it enough if the institution itself claims that it produces good outcomes, or if experts confirm that the output is good, or does output legitimacy not also require the recognition of other institutions as well as the public, i.e., broad agreement that the output is indeed good? If high politicisation continued over a longer term, one would eventually have to question whether such a high formal degree of ECB independence was in practice feasible and in general desirable from a democratic perspective.

In the following sections, the article will explore to what extent there has been politicisation and how it has evolved over time. In addition, it tests a number of hypotheses. Firstly, De Wilde et al. (2016) argue that the politicisation of EU governance is driven by the critics of the EU rather than its supporters. This would assume that the presence of strong critical voices pushes or keeps an issue on the agenda and that high levels of criticism will lead to more salience, i.e., more active scrutiny. If this holds true, the politicisation of ECB policy would indeed be the sign of a problem.

$\mathrm{H1}$ : Higher levels of criticism lead to more salience.
Secondly, Rauh (2014) argues that the salience of EU affairs in the plenary is linked, amongst other things, to supranational policy output and public visibility. In line with this, we also expect politicisation to increase after key ECB decisions or actions. If it holds true that politicisation is linked mainly to specific decisions or events, then politicisation might only be temporary, which means that disagreements might not cause problems in the longer term.

$\mathrm{H} 2$ : Politicisation increases after important ECB decisions or actions.

Thirdly, Degner and Leuffen (2016) find that, in the Bundestag, government membership and EU support are the main drivers of votes in favour of fiscal aid for Euro area member states. ECB policy-making is different, in that the German government is not a part of ECB decisions, whereas it can be held accountable for its role in the European Council in decisions on fiscal aid. Nevertheless, we will analyse, whether opposition parties are indeed more critical of ECB policy, especially those that are further away from the political centre. Governments are likely to be concerned that voters do not always distinguish who exactly has influence over any particular policy, and how much influence they actually have, but may instead tend to blame the state of affairs on those they perceive to be in charge. Even when voters are aware that it was another institution that took the decision, they may ask why the government did not intervene. Thus, governments have a certain interest in defending the state-of-affairs in general. Rauh (2014) also argues that government parties are the main drivers of scrutiny into EU affairs.

H3: Opposition parties are more critical of ECB policy than government parties.

H4: Government parties are more active than opposition parties in ECB scrutiny.

\section{Research Design}

The aim of the article is to assess how ECB policy has become politicised in the German Bundestag. De Wilde et al.'s definition of politicisation as a three-dimensional process involving increased salience, polarisation of opinion, and the expansion of actors involved in EU issues is used (De Wilde et al., 2016; cf. De Wilde, 2011; Hutter \& Grande, 2014). For this purpose, we will measure 'salience' through the number of plenary sessions in which MPs commented on ECB policy, polarisation as the occupation of more extreme positions over time by the different parties, and the expansion of actors and an increase in the number of MPs who comment on ECB policies in a given year.

The article analyses the plenary debates of the 16th, 17 th, 18th and beginning of the 19th legislative term of 
the German Bundestag (October 2005 to 31 December 2018). This time span was chosen as it includes years preceding the financial crisis, the financial crisis itself, the Eurozone crisis, and the stabilisation of the Eurozone after the crisis. In addition, the Eurosceptic right-wing populist Alternative for Germany (AFD) entered the Bundestag for the first time in 2017. By including the first years of the 19th parliamentary term, the impact of this new party can thus be analysed.

The relevant plenary debates were identified by a search for both the acronym 'EZB' and the term 'Zentralbank'. The resulting body was then manually coded to establish both the number of plenary sessions in which at least one MP commented on ECB policy and the number of speeches by MPs on ECB policy. This diversity of indicators will facilitate comparisons with other cases by other authors in the future: The number of speeches alone can be a difficult indicator for comparative studies, as some parliaments allow/have a culture of many interventions per debate, whereas other parliaments limit the number of speakers (e.g., to one expert per party). In the case of the Bundestag, there were several large debates where many speakers per party intervened, but also a range of smaller ones where most parties had one or two speakers, and only a few parties had more-presumably either because of a particular interest on the part of the party or its MPs. However, authors who work on parliaments with a more restrictive format of debates may find the number of sessions more representative/comparable than the number of speeches.

During data collection, documents were removed (or speeches skipped), only if the government mentioned the ECB or if the document or speech was not found to be relevant for an assessment of 'politicisation': This in- cludes, for example, cases where MPs referred merely to ECB data or statistics, mentioned that the ECB was at a meeting, or explained a technical process involving the ECB. These statements are not about 'ECB policy'. Speeches and sessions were only considered relevant if at least one sentence made a positive, negative, or neutral statement about an attitude, action, or decision of the ECB. The result is two sets of data: 212 plenary sessions and 309 speeches.

\section{Data Analysis}

De Wilde et al. (2016) identified the salience of a policy as the first dimension of politicisation. The evolution of the number of plenary sessions in the Bundestag in which at least one MP commented on the ECB's policies does show that the ECB gained political salience at certain points in time. However, this was not a linear process. Instead, in line with our expectations ( $\mathrm{H} 2)$, the salience came and went in waves that broadly reflect moments where the ECB played a particularly important role, gained new powers, or took controversial decisions. The only exception is the third and most recent wave of politicisation, which is driven primarily by party politics and the changing composition of the German parliament. The evolution of the number of speeches on ECB policy broadly mirrors this trend (Figure 1).

If the data on salience in Figure 1 is placed in the context of the changing content of the speeches over time, the fact that the first two waves are linked to certain ECB decisions, whereas the third wave is not, becomes visible: Thus, in 2005 and 2006, when the ECB was not confronted with any particularly difficult challenges, attention to the ECB was low, which is what one would

60

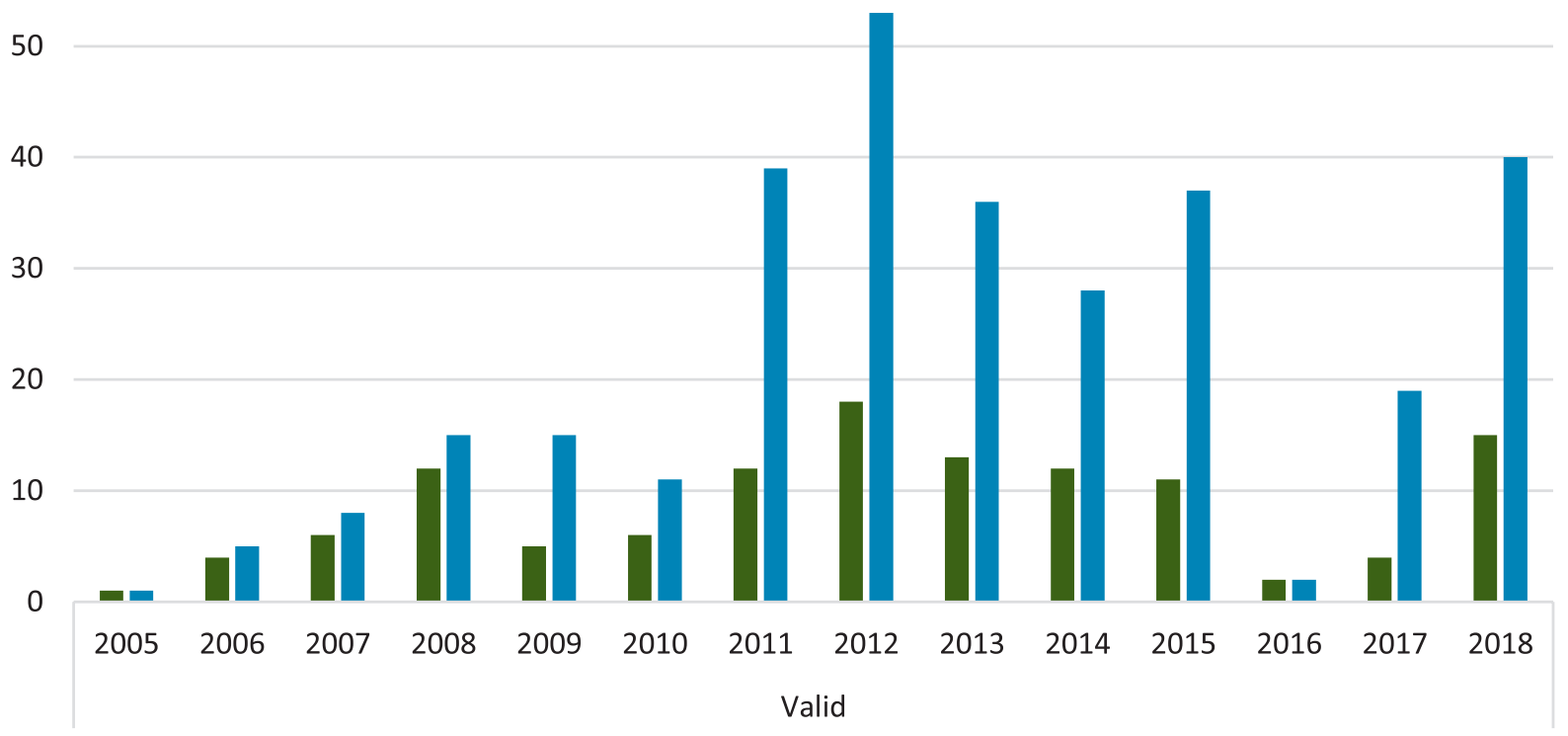

$\square$ No. of plenary sessions $\quad$ No. of plenary speeches

Figure 1. The number of speeches and plenary sessions on ECB policy over time. 
expect in the case of an institution that is supposed to be technocratic and independent. As parliaments have to cover a broad range of issues in a limited amount of time, they can be expected to focus primarily on policies where they can and should make a difference (e.g., legislate or mandate) or issues that are important in the eyes of voters. With the financial crisis of 2008 , the visibility of central banks increased, as the US Federal Reserve decided to lower the interest rate to support the economy, whereas the ECB chose to maintain a high interest rate. In this period, the ECB's decision to prioritize price stability (low inflation) over growth in line with its mandate in the Treaties was generally praised in the Bundestag. It was mainly the extreme left (Die Linke) that voiced dissatisfaction and the view that the ECB should focus on growth and jobs.

The attention then dropped again in 2009, although this is disguised in the data by the fact that there was one larger debate in which MPs voiced their frustration that the lowering of the interest rate by the ECB was not reflected in lower interest on loans for consumers. In 2010, it became clear that the financial crisis was morphing into a substantial sovereign debt crisis for several Eurozone states. As a result, speeches focused on the ECB's position on the Greek debt crisis and also on the question whether the ECB's bond-buying programmes (e.g., the Covered Bond Purchase Programme from May 2009 and the SMP that led the ECB to buy sovereign bonds issued by crisis countries) could compromise its independence.

The attention rose sharply in 2011 and 2012 remaining relatively high until 2015. In 2011, the speeches overwhelmingly focused on the legality and potential effects of the ECB's bond-buying. There were widespread concerns that this would lead to a communitarisation of debt, and that the German taxpayer would ultimately have to pay if one of those states defaulted. The language used to discuss the ECB became openly critical, and the ECB was repeatedly described as turning into a 'bad bank'. There were also some speeches on the ECB's role in the Troika, especially during the last quarter in the context of negotiations with Greece. The ECB's policies on increased liquidity (bond-buying, but also long term refinancing operations) remained the predominant theme in the first half of 2012 after the ECB took various measures to increase liquidity in late 2011/early 2012. However, there were also sporadic speeches about banking union in the context of the nascent European discussions. After the ECB's OMT announcement in the summer of 2012, the second half of the year continued to be dominated by these debates, but now about one third of the speeches focused on whether the ECB would be a good banking supervisor as the European Commission presented legislative proposals on banking union in September 2012. In the first quarter of 2013, the individual speeches started to focus more broadly on ECB crisis policies, including a range of measures from bond-buying to low interest rates to Troika decisions.
However, ELA to Cyprus was also becoming an issue of concern. The second quarter of 2013 was dominated by speeches about banking union in the context of EU lawmaking (several Council Regulations on banking union are adopted in October 2013). After a short lull in the second half of 2013 and the first quarter of 2014, the attention picked up again and became roughly evenly divided between ECB crises policies in general, ongoing concerns about the wisdom of making the ECB banking supervisor and concerns about low interest rates in the context of the ECB's foray into negative interest rates in June 2014. The case about the legality of the OMT programme before the European Court of Justice in October 2014 did not directly influence the debates. In 2015, low interest rates were the main concern, but there were also a number of speeches on the ECB's crisis policies more generally, and some speeches about the ECB's role in the Troika and the Greek crisis. The ECB's handling of Italian banks raised some concerns about a potential conflict of interest between its role as a central bank and its role as a banking supervisor.

After almost no attention was paid to ECB policy in 2016 (when the crisis has become less pressing), there were a few speeches in early 2017 that mainly focused on the ECB's low interest policy, and then the debate only resumed in late 2017 after the elections to the Bundestag. In the last quarter of 2017 throughout 2018 interest in ECB policy picked up again, but it was not driven by ECB decisions. The issues that were being debated had ongoing relevance of course (e.g., the interests were still low; the ECB still bought/held high volumes of bonds; the ECB still held sovereign bonds of countries that might at some point default; the potential conflict of interest between central bank and banking supervision tasks had not changed; the TARGET system was still showing large imbalances across countries). However, there are no ECBrelated events or decisions that can explain why the interest in so high in 2018, and yet so low in 2016 and most of 2017 (when all of the above were equally true). Rather, what changed is that a new party, the AFD, entered the Bundestag for the first time and scepticism of the ECB's policies was an important part of its agenda. This is also illustrated by Figure 2, which shows that, in the 19th term, the AFD is the source of roughly half of the comments on the ECB.

In general, the data on the speeches per party group do not confirm Rauh's (2014) argument that government parties drive EU issues in the Bundestag ( $\mathrm{H} 4)$. Between 2005-2009 (Christian Democratic Union-Social Democratic Party of Germany [CDU-SPD] coalition), all parties were similarly active, with the exception of the Greens who generally have a lower interest in this issue. In the 17th term (2009-2013), the governing CDU and Free Democratic Party (FDP) were somewhat less active than the opposition. Only from 2013-2017 were the governing parties (CDU and SPD) noticeably more active than the opposition, but this may also have been due to the fact that they were the biggest parties. Finally, since 


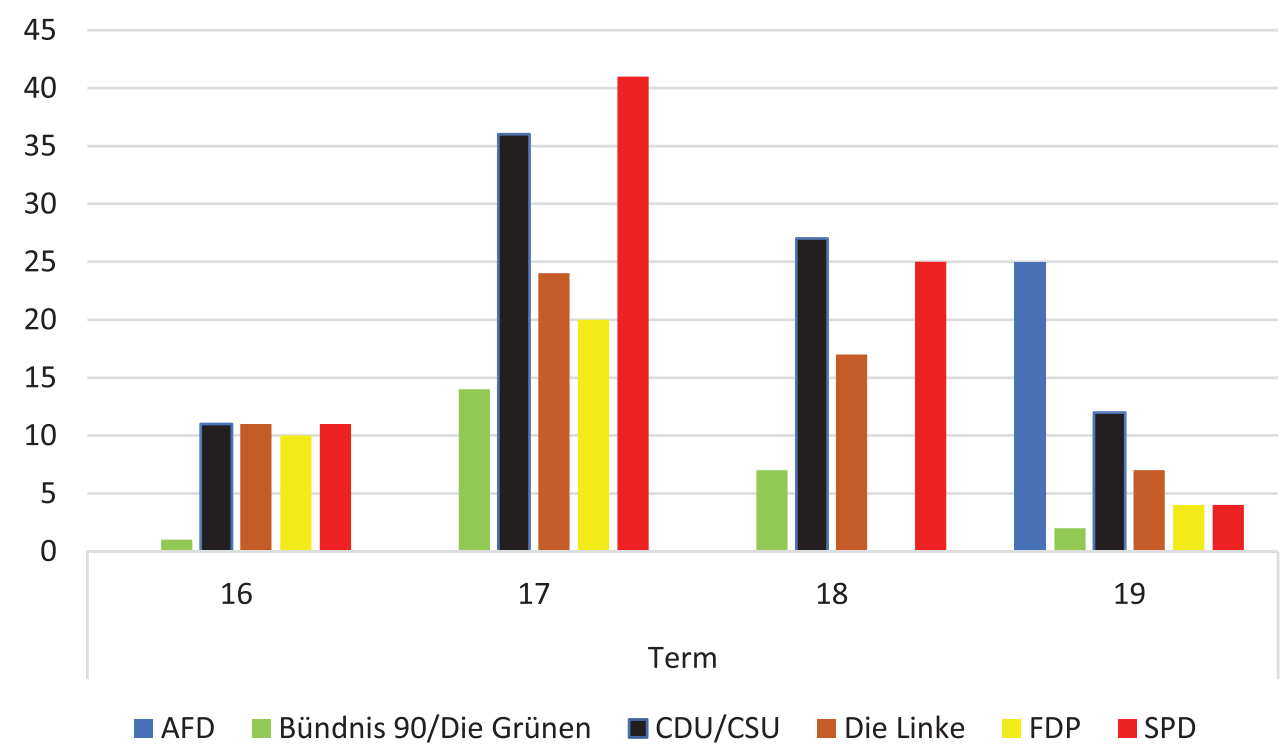

Figure 2. The number of speeches on ECB policy per party per parliamentary term.

2017 (CDU-SPD coalition), the AFD stand out as being the sole driver of ECB scrutiny.

Thus, having established that there were three waves in which the salience of the ECB increased and that this may now have become a long-term trend with a Eurosceptic party in parliament, the question is whether the second criteria-polarisation of opinion-is also present. For this purpose, Figure 3 shows the average po- sition taken by each of the parties during each legislative term. A positive score reflects praise, a negative score criticism (with the maximum values being 1 and -1 ).

First of all, the data largely confirm the hypothesis that government parties tend to be more supportive of ECB policies (H3). The governing CDU was generally relatively favourable or neutral towards the ECB. The SPD was also either neutral or positive in its views when it

\begin{tabular}{|l|c|c|c|c|}
\hline & & & & \\
\hline & & & & \\
\hline
\end{tabular}

Figure 3. The parties' positions on the ECB. Notes: The positions are measured on a 3 point scale: $1=$ praise, $0=$ neutral, $-1=$ criticism. The chart represents the average position per party in each legislative term. 
was in government after 2005 and 2013, and the FDP was no more sceptical than the other parties after 2009. In addition, the further opposition parties are from the middle of the political spectrum, the more critical they are of the ECB. This holds true for both Die Linke and the AFD. The one outlier is the Greens. This might be related to the fact that they are generally the least active party, and that ECB policy is not an important theme for them.

Figure 3 at best partially supports De Wilde et al.'s (2016) second element of politicisation, namely the assumption that politicisation comes with increased polarisation. As we saw previously, there were three waves of increased salience: a small wave during the 16th term (2008); a long and intense one during the 17th term (2011-2013), which continued on into the 18th term (until mid-2015); followed by a new intense wave in the 19th term. Two elements of the figure are striking: Firstly, the most intense moment of debate (17th term) is the term in which party positions converge the most. By contrast, the 16th parliamentary term (2005-2009), in which the ECB was far less salient a topic, had almost as much polarization as the current 19th term, when a Eurosceptic party entered the Bundestag. Does this mean that there is no clear pattern of politicisation? Or does it mean that polarisation is not the best or only measure of politicisation?

In fact, a closer look at the figure shows that an alternative measure of politicisation could be whether a parliament feels critical towards an actor or a policy. Thus, in this case, the high degree of polarisation before 2009 stems from the fact that most parties praised the ECB or were neutral, but one party (Die Linke) was sceptical as it considered that the ECB should have prioritized growth and jobs over price stability. The convergence between 2009 and 2013, on the other hand, stemmed from the fact that support for the ECB was in freefall. The CDU/CSU faction, which was almost fully supporting ECB policy before 2009 , was by that point only marginally favourable with the average position dropping by 0.88 points (on a 2-point scale!). The average position of the FDP dropped by a full point from very supportive to fairly critical. All the other parties were also predominantly critical of the ECB. Only Die Linke experienced a positive trend and became somewhat less critical. Overall, this convergence on a critical stance is clearly also a form of politicisation, especially in combination with the higher salience of the topic.

That said, one could argue that polarization does not have to be limited to a growing chasm between supporters and opponents of a policy or institutions. Critical statements that contradict each other could also be a form of polarization. In this case, however, the substance of the speeches also fails to show polarization. Of course, the convergence on a critical stance does not amount to a complete absence of disagreement between parties. One of the few fundamental differences is that Die Linke, for example, also tended to criticize the ECB for its role in the Troika, whereas the other parties focused predominantly on its bond-buying programmes, the low securities it accepted during the crisis, and the impact of the low interest policy on German savers and the housing market. There is thus one substantive difference between the line of argument of this party and the approach of other parties.

On the other hand, like the other parties, Die Linke also criticized the impact of the low interest policy on savers and the housing market-and this despite the fact that it had demanded a more expansionary policy that prioritized jobs over growth in the 2000s. The same ECBpolicy thus came under attack from both sides-the ordoliberals who felt that they reduced incentives for necessary structural reforms (and also hurt savers), and the left, who felt that the ECB's policies mostly benefitted banks and otherwise led to an expropriation of German savers. There were other commonalities, such as the widespread concern that the ECB's policy amounted to a communitarization of debt. On the whole, polarization thus decreased at the height of the crisis when the parliament was most active in its scrutiny. It decreased both in the sense that parties converged around a critical stance and in the sense that the actual arguments became more similar during this period compared to previous periods and were sometimes even shared across the whole political spectrum (e.g., the perception of the impact of the low interest policy). The interpretation of the ECB's pressure on the governments of debtor states was one of the few areas where the parties disagreed.

From late 2013 onward, the polarisation of opinions increased again, as some of the parties reconciled themselves to the ECB's policy. After 2017, the polarisation increased further. The landscape had, however, changed: The FDP, once very favourably disposed towards the ECB, became a critic of the ECB's monetary policy, though less extreme than the new AFD. Die Linke also returned to a very critical stance, mainly in response to the ECB's role in the Troika and the ECB's perceived lack of sensitivity towards social issues. This is in line with Wonka (2016) who found that Die Linke was particularly critical in its opinions on the crisis policies. However, in this case, other parties also had reservations about the ECB. The SPD and the Greens, once only moderately pro-ECB, are now strong supporters, and the $C D U$, once the biggest supporter, is less enthusiastic than before the crisis.

It is also interesting to note that the perceptions of different ECB activities vary. If we take the two biggest categories of ECB policy-its crisis policies on the one hand (i.e., interest policy, bond-buying programmes, Troika...) and its new functions as banking supervisor, we can see that it is possible for the approval of one type of ECB policy to increase while approval for the other falls (cf. Figure 4). In term 17, when the crisis policies were most negatively perceived, the positive and negative views on the ECB's potential role as banking supervisor cancelled each other out. When the MPs reconciled themselves to the crisis policies, support for the ECB's banking supervision conversely dropped. This was due to 
.60

.40

.20

.00
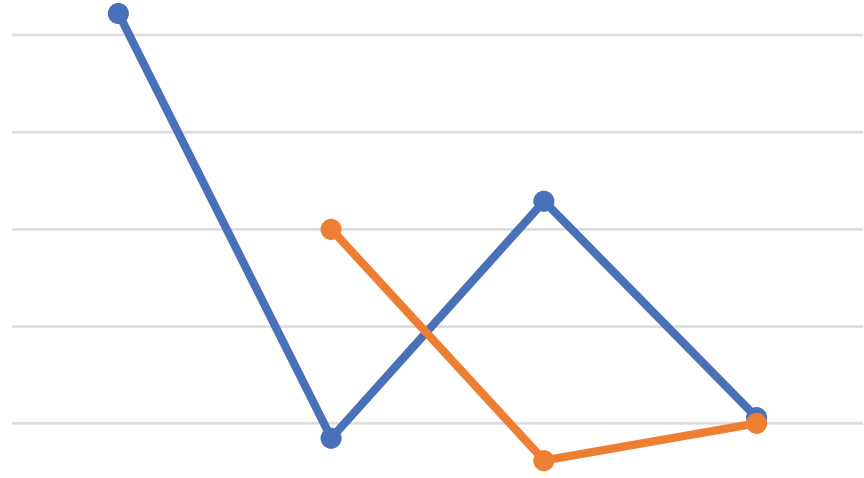

$-.40$

$-.60$

\begin{tabular}{|c|c|c|c|c|}
\hline \multirow[b]{2}{*}{-.60} & \multirow[b]{2}{*}{16} & & \multirow[b]{2}{*}{19} \\
\hline & & 17 & 18 & \\
\hline crisis policies & .44 & -.43 & .06 & -.39 \\
\hline - banking supervision & & .00 & -.48 & -.40 \\
\hline
\end{tabular}

Figure 4. Positions on the crisis policies and the ECB's role in banking supervision. Notes: The positions are measured on a 3 point scale: $1=$ praise, $0=$ neutral, $-1=$ criticism. The chart represents the average position per legislative term.

the fact that MPs saw a conflict of interest in the ECB's role as a lender of last resort, its financial stakes in the survival of some of the problematic Greek and Italian banks, and its role as a banking supervisor responsible for declaring whether a bank is indeed still viable.

However, while there were moments where high salience did indeed coincide with high levels of criticism, as during the second wave of politicisation (2011-2014), $\mathrm{H} 1$ (that higher levels of criticism lead to higher levels of salience) is overly simplistic. It is indeed the case that salience tends to be higher in years where MPs are critical of ECB policy. However, as Figure 5 shows, the relationship between criticism and salience is by no means linear. Firstly, and unsurprisingly, years with very little activity can produce outliers (e.g., in 2005, where only one MP commented on the ECB, we have a perfect score of -1 ). Causality may be reversed for those cases of very low salience, in the sense that MPs who speak about an issue that is not really on the agenda and that is not considered important at the time are likely to be those who hold stronger views on the issue. Secondly, and more problematically for the hypothesis, 2015 saw a comparatively high level of activity despite a slightly positive score (0.05), as MPs became more reconciled with the ECB as the Eurozone crisis abated. That said, the hypothesis has become more relevant in recent years, as the AFD actively pushes the issue in debates and has also triggered plenary debates (e.g., on the TARGET2 balance, in autumn 2018).

Finally, having established that there is politicisation in the form of increased salience and a generally critical stance, the question is whether there is also increased politicisation in terms of the numbers of actors involved in parliament. Figure 6 shows that the number of MPs

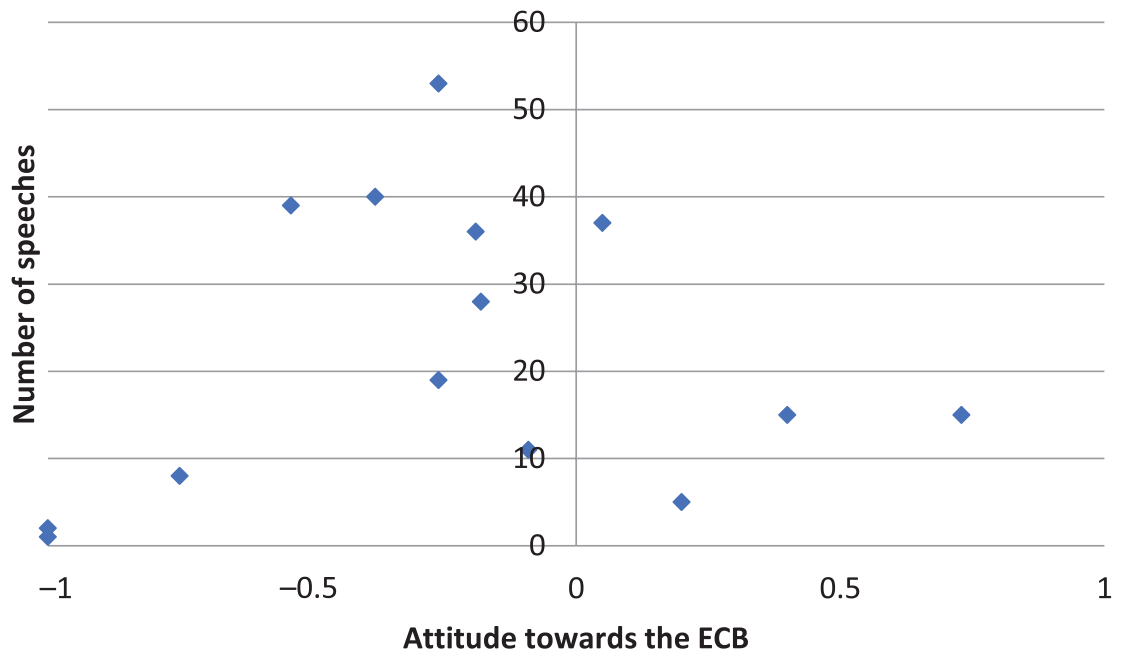

Figure 5. Criticism of the ECB and salience. 


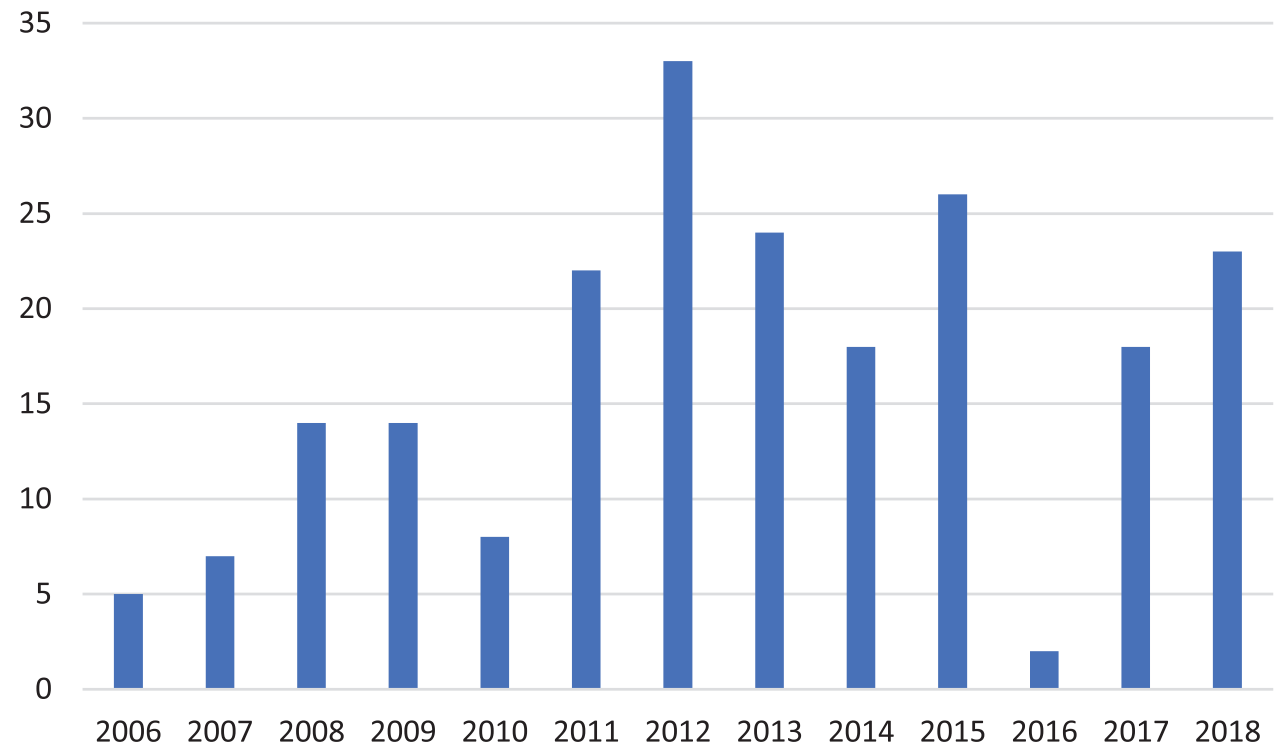

Figure 6. Number of MPs making ECB-related speeches per year. Note: 2009, 2013 and 2017 were election years.

who comment on ECB policies has indeed increased over time, compared to the pre-crisis years. The exception is again 2016 until autumn 2017, as the parliament temporarily lost interest in the ECB. That said, the number of MPs commenting on this issue is still quite small in relation to the size of the Bundestag (currently 709 seats). It is important to note, though, that several prominent politicians made speeches about ECB policies during the crisis, such as Lafontaine and Wagenknecht for Die Linke, Steinbrück and Steinmeier for the SPD, Kauder for the CDU, Weidel for the AFD, Trittin for the Greens, and Brüderle for the FDP. This may reflect the fact that the topic is normally one that requires expertise, but that it was also electorally salient as German voters were concerned about the impact of low interest rates on their savings, the stability of the Euro or the potential risks of the ECB's bond-buying programmes for Germany.

\section{Conclusion}

The ECB's active role during the crisis did indeed come at the cost of politicisation-at least temporarily. Thus, the German parliament had traditionally been a strong supporter of central bank independence, had only paid limited attention to the ECB during the financial crisis and was generally quite positively disposed towards ECB policies. Many MPs praised the ECB for prioritizing stability over growth, and criticisms were often disguised as polite suggestions.

After 2009, the picture changed. Not only did the Bundestag discuss ECB policies more actively, but it also became more critical. Polite suggestions turned into open criticism or even accusations, for example, that the ECB illegally financed states and that its low interest policy expropriated savers. This change is surprising given the Bundestag's long tradition of restraint in its scrutiny of Germany's own central bank. Terms like 'money press', 'expropriation', 'violation of the Treaties', 'illegal', 'misguided', and 'flood of money' became part of the vocabulary. And when a movement created in this period entered parliament in 2017, it revived this vocabulary after a brief period of depolitisation. On the whole, we have seen three waves of politicisation: the second and third waves, in particular, brought high levels of polarisation or criticism and greater levels of parliamentary activity and a wider range of active MPs. While there is no clear government-opposition divide in terms of the level of activity, the criticism today mainly comes from opposition parties, and especially from the far left and right.

Today, the MPs of the mainstream parties still frequently repeat that ECB independence is an important principle, but from the way they speak about these topics, it is clear that trust in the ECB has eroded. A comparison with Högenauer and Howarth's (2018) article on the Bundestag and the Bundesbank also confirms that the ECB is criticised frequently, whereas the Bundesbank is virtually never criticised in parliament, and that the ECB is discussed far more often than its national counterpart. Independence clearly no longer protects the ECB from criticism the way it protects the Bundesbank.

Interestingly, while the first two waves of politicisation were linked to prominent ECB decisions or policies, the third wave is mainly linked to the changing German political landscape after the 2017 elections. This third wave of politicisation was ongoing as of early 2019 , and the effects of this politicisation will probably still be felt for some time, given that a Eurosceptic party founded on the back of a rejection of EU crisis policies has entered parliament. In addition, the ECB's new role as banking supervisor means that it is likely to return to the spotlight from time to time: As the ECB is facing a conflict of interest in its role as both lender and supervisor, it will most likely be closely watched each time a major bank is in crisis. It does not appear that a return to depolitisation is 
likely in the near future, but the data also shows that depoliticisation could happen in the right context. Whether politicization will continue in the long-term will depend both on the German political context and especially on the future evolution of Eurosceptic parties, as well as on the challenges the ECB will face in monetary policy and banking supervision.

From a democratic perspective, this politicisation is a challenge. It may be a good thing when politicisation occurs in policy areas where increased scrutiny can lead to better input into policies or a greater willingness to hold actors accountable. But is controversy and criticism fruitful in areas that are supposed to be relatively apolitical? And can a high degree of ECB independence still be democratically justified, if the policy area ceases to be technocratic and apolitical and turns into something that becomes regularly politically contested?

\section{Acknowledgments}

I would like to thank the reviewers for their helpful and constructive comments and the guest editors, Christine Neuhold and Guri Rosén, for their support.

\section{Conflict of Interests}

The authors declare no conflict of interests.

\section{References}

Amtenbrink, F., \& van Duin, K. (2009). The European Central Bank before the European Parliament: Theory and practice after 10 years of monetary dialogue. European Law Review, 34(4), 561-583.

Auel, K., \& Höing, O. (2014). Parliaments in the Euro crisis: Can the losers of integration still fight back? Journal of Common Market Studies, 52(6), 1184-1193.

Auel, K., \& Raunio, T. (2014). Debating the state of the Union? Comparing parliamentary debates on EU issues in Finland, France, Germany and the United Kingdom. Journal of Legislative Studies, 20(1), 12-28.

Auel, K., Rozenberg, O., \& Tacea, A. (2014). Measuring parliamentary strength and activity in EU affairs. In C. Hefftler, C. Neuhold, O. Rozenberg, J. Smith, \& W. Wessels (Eds), The Palgrave handbook of national parliaments and the European Union (pp. 60-93). London: Palgrave Macmillan.

Börzel, T. A., \& Risse, T. (2018). From the Euro to the Schengen crises: European integration theories, politicisation, and identity politics. Journal of European Public Policy, 25(1), 83-108.

Closa, C., \& Maatsch, A. (2014). In a spirit of solidarity? Justifying the European Financial Stability Facility (EFSF) in national parliamentary debates. Journal of Common Market Studies, 52(4), 826-842.

De Wilde, P. (2011). No polity for old politics? A framework for analyzing the politicisation of European integration. Journal of European Integration, 33(5),
550-575.

De Wilde, P., Leupold, A., \& Schmidtke, H. (2016). Introduction: The differentiated politicisation of European governance. West European Politics, 39(1), 3-22.

Degner, H., \& Leuffen, D. (2016). Keynes, Friedman or Monnet? Explaining parliamentary voting behavior on fiscal aid for euro area member states. West European Politics, 39(6), 1139-1159.

European Central Bank. (n.d.). Key ECB interest rates. European Central Bank. Retrieved from https:// www.ecb.europa.eu/stats/policy_and_exchange_ rates/key_ecb_interest_rates/html/index.en.html

European Commission. (2007). Standard Eurobarometer Survey No. 67. Retrieved from https://ec.europa.eu/ commfrontoffice/publicopinion/index.cfm/Survey/ getSurveyDetail/instruments/STANDARD/surveyKy/ 617

European Commission. (2009). Standard Eurobarometer Survey No. 71. Retrieved from https://ec.europa.eu/ commfrontoffice/publicopinion/index.cfm/Survey/ getSurveyDetail/instruments/STANDARD/surveyKy/ 617

Flachmeyer, M., \& Paul, A. T. (2018). Bridge over troubled waters. Die EZB, die Euro-Rettung und die Politisierung der Geldpolitik [The ECB, the saving of the Euro and the politicisation of monetary policy]. Kölner Zeitschrift für Soziologie und Sozialpsychologie, 70(1), 495-515.

Fromage, D., \& Ibrido, R. (2018). The 'banking dialogue' as a model to improve parliamentary involvement in the monetary dialogue? Journal of European Integration, 40(3), 295-308.

Goodhart, C., \& Lastra, R. (2018). Populism and Central Bank independence. Open Economic Review, 29(1), 49-68.

Heft, A. (2017). National orientations or a common European debate? The representations of the beginnings of the Greek and Euro crises in German and Spanish quality press. Javnost-The Public, 24(1), 49-70.

Högenauer, A.-L., \& Howarth, D. (2018). The parliamentary scrutiny of euro area national central banks. Public Administration. https://doi.org/10.1111/ padm.12576

Högenauer, A.-L., \& Howarth, D. (2019). The democratic deficit and European Central Bank crisis monetary policies. Maastricht Journal of European and Comparative Law, 26(1), 81-93.

Höing, O. (2013). Differentiation of parliamentary powers. The German Constitutional Court and the German Bundestag within the financial crisis. In $\mathrm{M}$. Cartabia, N. Lupo, \& A. Simoncini (Eds), Democracy and subsidiarity in the EU. National parliaments, regions and civil society in the decision-making process (pp. 255-280). Rome: II Mulino.

Hutter, S., \& Grande, E. (2014). Politicising Europe in the national electoral arena: A comparative analysis of five West European countries, 1970-2010. Journal of Common Market Studies, 52(5), 1002-1018. 
Leupold, A. (2016). A structural approach to politicisation in the Euro crisis. West European Politics, 39(1), 84-103.

Moschella, M. (2017). When some are more equal than others: National parliaments and intergovernmental bailout negotiations in the Eurozone. Government and Opposition, 52(2), 239-265. https://doi.org/10. 1017/gov.2016.49

Rauh, C. (2014). Communicating supranational governance? The salience of EU affairs in the German Bundestag 1991-2013. European Union Politics, 16(1), 116-138.

Raunio, T. (2009). National parliaments and European integration: What we know and agenda for future research. Journal of Legislative Studies, 15(4), 317-334.

Scicluna, N., \& Auer, S. (2019). From the rule of law to the rule of rules: Technocracy and the crisis of EU governance. West European Politics, 42(7), 1420-1442.

Tesche, T. (2018). Instrumentalizing EMU's democratic deficit: The ECB's unconventional accountability measures during the Eurozone crisis. Journal of European Integration, 2018, 1-17. https://doi.org/10. 1080/07036337.2018.1513498

Wendler, F. (2014). Justification and political polarization in national parliamentary debates on EU Treaty reform. Journal of European Public Policy, 21(4), 549-567.

Wiesmann, G., \& Steen, M. (2012, October 25). Draghi battles to convince Bundestag critics. Financial Times. Retrieved from https://www.ft.com/content/ 34f3608a-8598-11e6-8897-2359a58ac7a5

Winzen, T. (2012). National parliamentary control of European Union affairs: A cross-national and longitudinal comparison. West European Politics, 35(3), 657-672.

Wonka, A. (2016). The party politics of the Euro crisis in the German Bundestag: Frames, positions and salience. West European Politics, 39(1), 125-144.

\section{About the Author}

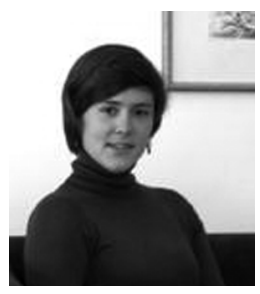

Anna-Lena Högenauer is Maitre-Assistant de Recherche in the Institute of Political Science of the University of Luxembourg. She previously worked as Postdoctoral Researcher at Maastricht University and holds a PhD in Politics from the University of Edinburgh. She works on multi-level governance, democracy and parliamentary control of European policy-making and was an active member of the Observatory of Parliaments after Lisbon (OPAL, www.opal-europe.org) and the Erasmus Network on Parliamentary Democracy in Europe (PADEMIA, http://www.pademia.eu). 